\title{
Stimulus Kelompok Orangtua Siswa SD Ar Rasyid Dalam Menciptakan Masyarakat Produktif Ekonomi
}

\author{
Ruri Aditya Sari*1, Iswandi Idris ${ }^{2}$, Syahril ${ }^{3}$, Agnita Yolanda ${ }^{4}$, Nurismilida $^{5}$ \\ 1,4Program Studi Administrasi Bisnis, Politeknik LP3I Medan \\ ${ }^{2}$ Program Studi Teknologi Komputer, Politeknik LP3I Medan \\ 3Program Studi Akuntansi, Politeknik LP3I Medan \\ ${ }^{5}$ Fakultas Sastra, Universitas Islam Sumatera Utara \\ *e-mail: ruri@lp3i.id¹, iswandi.idris@gmail.com² , syahril@lp3i.id³, agnitayo@gmail.com4, \\ eminuris@gmail.com ${ }^{5}$
}

\begin{abstract}
Women are given chance to do as carreer women and housewives. However, some women got married in productive ages choose to be a career woman. A group of mothers in TK Ar Rasyid Tanjung Selamat, Sunggal,Deli Serdang, there are 15 mothers with 27-35 years old unproductive society financially become partners of stimulus community dedication. It aims to help group of students' mothers, additional knowledge, skill, welfares through income commission and help partners to spend their leisure Time by doing meaningful activities both physically and mentally. Some solutions are offered, such as cooking healthy meals training to gain value for sale and modern with low budget. They are like rolled age,BBQ fried chicken training, bread pudding training,online marketing and deciding prices training and also arranging treasury. Through this stimulus community dedication, it would add partenrs' knowledge $80 \%$ and partners' creativity improved up to $65 \%$.
\end{abstract}

Keywords: cooking training, PKMS, egg, bread, marketing, cash

\begin{abstract}
Abstrak
Wanita diberikan kesempatan untuk sebagai wanita karir dan sebagai ibu rumah tangga. Namun, sebagian wanita menikah usia produktif memilih untuk menjadi ibu rumah tangga. Kelompok ibu - ibu orangtua siswa kelas 1 dan 2 SD Ar Rasyid Tanjung Selamat, Sunggal, Deli Serdang beranggotakan sebanyak 15 orang yang berusia 27 - 35 tahun tergolong masyarakat tidak produktif secara ekonomi yang menjadi mitra pengabdian kepada masyarakat stimulus (PKMS). Tujuannya untuk membantu kelompok ibu orangtua siswa menambah pengetahuan, keterampilan, kesejahteraan hidup melalui penambahan income dan membantu mitra untuk mengisi waktu luang dengan kegiatan yang bermanfaat bagi fisik dan mental. Solusi yang ditawarkan adalah memberikan pelatihan memasak cemilan sehat yang memiliki nilai jual dan bersifat modern serta ber-badget rendah seperti Pelatihan telur gulung, pelatihan BBQ Fried Chicken, pelatihan puding roti, pelatihan pemasaran online dan pelatihan penentuan harga jual dan penyusunan kas. Melalui PKMS ini menambah pengetahuan mitra sebanyak 80\% dan mitra yang kreatif meningkat sebanyak $65 \%$.
\end{abstract}

Kata kunci: pelatihan memasak, PKMS, telur, roti, pemasaran, kas

\section{PENDAHULUAN}

Penjualan melalui online merupakan salah satu kelompok ekonomi kreatif di Indonesia. Ekonomi kreatif merupakan sebua konsep yang dinilai baru oleh masyarakat. Tingkat prosentasi pertumbuhan wirausaha di Indonesia yang hanya 3\% di tahun 2017(Kompas, 2018). Ekonomi kreatif mengintensifkan kreativitas dan informasi dengan mengandalkan ide dan pengetahuan sebagai faktor produksi dan memiliki peran dalam pembangunan ekonomi dan pengembangan bisnis (Yudha, 2017). Pemerintah memberikan perhatian kepada pertumbuhan ekonomi kreatif, yang terbukti dengan dibahasnya Undang - undang yang mengatur tentang kewirausahaan Nasional dan Peraturan Pemerintah Republik Indonesia Nomor 41 Tahun 2011 tentaang Pengembangan Kewirausahaan dan Kepeloporan Pemuda, Serta Penyediaan Prasarana dan Sarana Kepemudaan. Terdapat kesenjangan daya saing pelaku usaha kecil, mikro dan menengah dibandingkan dengan usaha besar. Untuk memperkecil gap tersebut serta meningkatkan angka pertumbuhan ekonomi kreatif maka diperlukan akselerasi pengembangan wirausaha baik dari 
penumbuhan wirausaha baru maupun peningkatan kualitas wirausaha secara berkesinambungan (Bappenas, 2013).

Berdasarkan Prakoswa (2018), jumlah tenaga kerja perempuan lebih sedikit dibandingkan dengan tenaga kerja laki-laki dari segala bidang pekerjaan. Sehingga gap pendapatan perempuan dengan lelaki dipengaruhi oleh jumlah tenaga kerja perempuan yang bekerja di sektor produktif masih sedikit dibandingkan dengan laki - laki. Berdasarkan Badan Pusat Statistik (BPS) (Prakoswa, 2018), upah bersih pekerja perempuan tercatat sebesar Rp. 2,3 juta/bulan pada bulan Agustus 2017. Angka tersebut meningkat dari tahun sebelumnya, selanjutnya indeks pembangunan manusia (IPM) laki - laki berada di atas nilai 70 termasuk kategori "tinggi", sedangkan perempuan pada level "sedang" (Prakoswa, 2018). Data tersebut menunjukkan bahwa, perempuan Indonesia masih banyak yang tidak produktif terutama ketika sudah menikah, walaupun usia mereka tergolong usia produktif.

Wanita mempunyai kesempatan untuk memiliki peran ganda, sebagai ibu rumah tangga dan sebagai wanita karir, namun prosentase wanita yang memilih untuk tidak tampil dan berperan dalam kehidupan bermasyarakat juga masih banyak dtemui. Menurut Siadari (2015) status perkawinan, tingkat pendidikan, tingkat umur, status rumah tangga, pendapatan suami dan jumlah anak usia dini mempengaruhi kemungkinan partisipasi angkatan kerja wanita sudah menikah. Kebanyakan aktivitas wanita menikah yang tidak bekerja adalah mengantar dan menjemput anak - anak nya pergi dan pulang sekolah. Terutama wanita yang memiliki anak berusia 3-7 tahun. Namun, partisipasi wanita dinilai dapat membantu pembangunan dan pengembangan ekonomi suatu negara. Walaupun, masih ada wanita yang sudah menikah memilih untuk tidak bekerja, namun masih ada upaya lain yang dapat dilakukan untuk meningkatkan kesejahteraan hidup dan membantu perkembangan perekonomian negara. Adapun upaya yang dapat dilakukan adalah dengan mendidik wanita untuk menjadi wirausaha. Pendidikan merupakan usaha yang dilakukan untuk mengubah tingkah laku seseorang (Sukidjo, 2012). Melalui pendidikan, kekuatan intelektual, daya moral dan daya sosial dapat dikembangkan. Kewirausahaan merupakan salah perilaku, semangat dan kemampuan seseorang dalam menangani kegiatan yang menciptakan, mencapai dan menerapkan cara kerja, teknologi dan produk baru secara efisiensi untuk memberikan pelayanan yang lebih baik untuk memperoleh keuntungan yang besar (Sukidjo, 2012).

SD Ar Rasyid merupakan Sekolah Dasar yang berlokasi di Tanjung Selamat, Sunggal, Deli Serdang Regency. Sekolah Dasar ini memiliki murid sebanyak 60 orang yang berusia dari $7-12$ tahun. SD Ar Rasyid ini berada di komplek perumahan penduduk, murid SD kelas 1 dan 2 masih diantar dan di temani oleh ibunya. Sekolah Dasar ini mempunyai jadwal selayaknya SD pada umumnya yaitu siswa masuk dari jm 07.30 dan pulang jam 11.00. Berdasarkan pengamatan, diperoleh bahwa selama menunggu anak belajar di sekolah, hal yang biasa dilakukan para ibu adalah bercerita, makan bersama, gosip, arisan, memamerkan barang baru, belanja, ke salon, pengajian, piknik, membahas sosial media, membuat baju seragam dan lainnya. Sehingga karena terlalu asyik berkumpul dengan sesama ibu, tanpa disadari anak - anak mereka sudah keluar dari kelas, tak sedikit yang mengabaikan anak - anak mereka setelah diluar jam sekolah. Hal ini membuat anak - anak SD terutama kelas 2 tersebut, meminta uang jajan kepada sang ibu dan memilih jajanan yang tidak sehat. Terdapat $>5$ orang anak dari kelompok ibu tersebut memiliki berat badan yang overweight dan terdapat $>20$ orang anak yang kekurangan berat badan. Jumlah anak overweight dan kekurangan berat badan ini menjadi perhatian, karena mereka merupakan generasi penerus bangsa. Pada dasarnya aktivitas para ibu adalah sesuatu yang tidak penting, karena dari semua kegiatan tersebut banyak yang mengakibatkan dampak negatif seperti menimbulkan kesombongan diri, ajang pamer, saling iri, pemborosan, bertengkar, saling memusuhi, dan fitnah. Kejadian ini tidak hanya berdampak pada anak namun juga akan mempengaruhi kehidupan keluarga. Akan terjadi perubahan pola hidup yang dapat mengganggu kestabilan perekonomian keluarga. Dampak terburuknya dapat mengakibatkan kurang harmonisnya kehidupan keluarga. Di sisi lain berdampak pada kesehatan anak termasuk 
pertumbuhan dan perkembangan anak, yang diakibatkan dari kelalaian para ibu dalam mengontrol jajanan anak.

Mitra PKMS merupakan kelompok ibu - ibu orangtua murid SD Kelas 1 dan 2 SD Ar Rasyid yang beranggotakan sebanyak 15 orang yang berusia produktif ( 27 - 35 tahun) yang tergolong dalam masyarakat non produktif secara ekonomi, memiliki semangat untuk belajar dan merupakan ibu - ibu yang sangat teliti dalam mengerjakan sebuah pekerjaan (hal ini terlihat dari cara mereka dalam merencanakan dan mengadakan sebuah kegiatan). Kelompok ibu orangtua siswa ini merupakan kelompok orangtua siswa yang memiliki taraf hidup yang berbeda - beda. Para ibu orangtua siswa tersebut bertugas mengantar dan menemani anak - anak mereka bersekolah di SD Ar Rasyid, karena jadwal sekolah selama >3 jam, maka para ibu tersebut sering berkumpul bersama di kantin depan sekolah. Kebanyakannya kegiatan mereka selama menunggu anak - anak mereka selesai belajar adalah bercerita, berdiskusi, menggosip, arisan, menawarkan beberapa barang, saling bertukar pikiran sampai berlibur bersama. Namun kegiatan tersebut kurang memberikan manfaat pada kehidupan dan kesejahteraan hidup. Selama ini mereka telah menyusun kegiatan perjumpaan rutin setiap bulannya berupa arisan. Agenda arisan adalah mengumpulkan sejumlah uang setiap bulan untuk pinjaman bergilir (jula - jula). Masalah yang dihadapi mitra adalah terjadinya kesenjangan antara ibu - ibu murid yang ekonomi menengah dengan ekonomi tinggi. Hal ini disebabkan oleh pertemuan yang diadakan setiap bulannya tidak mengandung kegiatan yang bermanfaat. Sehingga mengakibatkan kesenjangan dan kurang harmonis. Kesenjangan dan harmonis ini membawa dampak pada sikap dan perilaku anak. Hal ini ditunjukkan oleh beberapa sikap anak yang meniru perlakuan kesenjangan antara ekonomi menengah dengan ekonomi tinggi. Fenomena ini merupakan masalah mitra yang utama dan sudah sampai pada tahap mengkhawatirkan (sumber: ketua kelompok ibu - ibu orangtua siswa). Ketua kelompok menilai bahwa saat ini sudah terjadi kesenjangan yang sangat besar dan ketidak harmonisan antara para ibu, terlihat dari adanya kelompok - kelompok ibu - ibu. Oleh karena itu, kelompok mitra merasa perlu untuk dirancang kegiatan yang memberikan dampak positif, bermanfaat dan dapat meningkatkan kesejahteraan hidup para ibu. Berdasarkan hasil diskusi dengan para ibu, mereka menyatakan membutuhkan pelatihan yang dapat membantu meningkatkan taraf hidup keluarga walau tetap menjadi ibu rumah tangga. Diharapkan nantinya melalu kegiatan ini dapat berlanjut pada peningkatan perekonomian desa melalui Bumdes (Amrina, et al., 2019).

\section{METODE}

Pelatihan dilaksanakan dengan 2 (dua) metode yaitu secara online dan offline. Pelatihan online dilaksanakan dengan menggunakan Zoom. Pelatihan yang dijalankan terdiri dari Pelatihan Membuat Telur Gulung, Pelatihan Membuat Ayam BBQ, Pelatihan Membuat Puding Telur, Pelatihan Pemasaran Online dan Pelatihan Penentuan harga jual serta Pengelolaan Kas. Setiap jenis pelatihan dilaksanakan $5 x$ pertemuan. Gambar 1 merupakan gambaran pelaksanaan kegiatan.

\section{Lokasi Kegiatan}

Sehubungan situasi Pandemi Covid-19, kegiatan dilaksanakan di rumah Ketua Kelompok orang tua siswa kelas 1 dan 2 SD Ar Rasyid Desa Sukamaju, Kecamatan Sunggal, Deli Serdang.

\section{Metode Pelaksanaan Pelatihan Telur Gulung}

Terdapat beberapa langkah yang dilakukan untuk pelatihan membuat telur gulung yaitu:
a. Dilakukan sosialisasi/pemahaman tentang teknik telur gulung dan bahan - bahan yang diperlukan yang dilakukan 5 hari sebelum pelaksanaan pelatihan
b. Dilakukan sosialisasi pengenalan bahan dan alat yang akan digunakan
c. Dilakukan pelatihan memasak/membuat telur gulung dengan metode ceramah dan praktek sebanyak $5 \mathrm{x}$ pertemuan


d. Pada pertemuan I : pengenalan teknik telur gulung, bahan dan alat perlengkapan, dan melatih menggulung telur. Memberikan tugas 2 telur gulung biasa.

e. Pertemuan II : belajar membuat telur gulung dengan variasi rasa (rasa sosis, rasa jamur dan rasa rumput laut)

f. Pertemuan III - V : memodifikasi telur gulung dengan menambahkan saos atau mayonaise. PIC : Ruri Aditya Sari, M.Sc (moderator), Siska Hasibuan, S.Sos, M.Pd (pembicara) dan tim pengusul sebagai pelaksana

\section{Metode Pelaksanaan Pelatihan BBQ Fried Chicken}

Terdapat beberapa langkah yang dilakukan untuk pelatihan BBQ Fried Chicken yaitu :

a. Dilakukan sosialisasi/pemahaman tentang teknik penting yang dilakukan 5 hari sebelum pelaksanaan pelatihan

b. Dilakukan sosialisasi pengenalan bahan dan alat yang akan digunakan

c. Dilakukan pelatihan memasak/membuat $B B Q$ Fried Chicken dengan metode ceramah dan praktek sebanyak $5 x$ pertemuan

d. Pada pertemuan I : pengenalan $B B Q$ Fried Chicken, bahan dan alat perlengkapan, dan melatih membuatnya

e. Pertemuan II : pelatihan $B B Q$ Fried Chicken rasa original

f. Pertemuan III - V : pelatihan BBQ Fried Chicken memodifikasi tingkat kepedasan

PIC : Ruri Aditya Sari, M.Sc (moderator), Siska Hasibuan, S.Sos, M.Pd (pembicara) dan tim pengusul sebagai pelaksana

Prosedur Pembuatan $B B Q$ Fried Chicken :

\section{Metode Pelaksanaan Pelatihan Puding Roti}

Terdapat beberapa langkah yang dilakukan untuk pelatihan Puding Roti yaitu :

a. Dilakukan sosialisasi/pemahaman tentang teknik yang dilakukan 5 hari sebelum pelaksanaan pelatihan

b. Dilakukan sosialisasi pengenalan bahan dan alat yang akan digunakan

c. Dilakukan pelatihan membuat puding roti dengan metode ceramah dan praktek sebanyak $5 x$ pertemuan

d. Pada pertemuan I : pengenalan teknik, bahan dan alat perlengkapan, dan melatih membuatnya

e. Pertemuan II : pelatihan menyempurnakan puding roti

f. Pertemuan III - V : modifikasi memasak puding roti dengan memanggang dan mengukus

PIC : Ruri Aditya Sari, M.Sc (moderator), Siska Hasibuan, S.Sos, M.Pd (pembicara) dan tim pengusul sebagai pelaksana

\section{Metode Pelatihan Pemasaran Online}

Terdapat beberapa langkah yang dilakukan untuk pelatihan pemasaran online yaitu :

a. Dilakukan sosialisasi/pemahaman tentang kait yang dilakukan 5 hari sebelum pelaksanaan pelatihan

b. Dilakukan sosialisasi pengenalan fitur - fitur aplikasi yang akan digunakan

c. Dilakukan pelatihan pemasaran online dengan metode ceramah dan praktek sebanyak $5 \mathrm{x}$ pertemuan

d. Pada pertemuan I : pengenalan media online, pengenalan fitur - fitur aplikasi

e. Pertemuan II : pelatihan menghias produk sebelum di foto, mengambil gambar produk

f. Pertemuan III - V : pelatihan menyusun gambar produk dan keterangannya di aplikasi online

PIC : Iswandi Idris, ST, MT (pembicara), dan tim pengusul sebagai pelaksana

Metode Pelatihan Penentuan harga produk dan pengelolaan kas

Terdapat beberapa langkah yang dilakukan untuk pelatihan Penentuan harga produk dan pengelolaan kas yaitu : 
a. Dilakukan sosialisasi/pemahaman tentang kait yang dilakukan 5 hari sebelum pelaksanaan pelatihan

b. Dilakukan sosialisasi pengenalan tentang harga produk

c. Dilakukan pelatihan dengan metode ceramah dan praktek sebanyak $2 x$ pertemuan

d. Pada pertemuan I : pengenalan tentang harga produk, pengenalan variabel - variabel penentu harga

e. Pertemuan II : pelatihan menghitung untuk penentuan harga produk dan pengelolaan kas PIC : Agnita Yolanda, B.Comm, M.Sc (pembicara), Syahril, SE, M.Si (moderator) dan tim pengusul sebagai pelaksana.
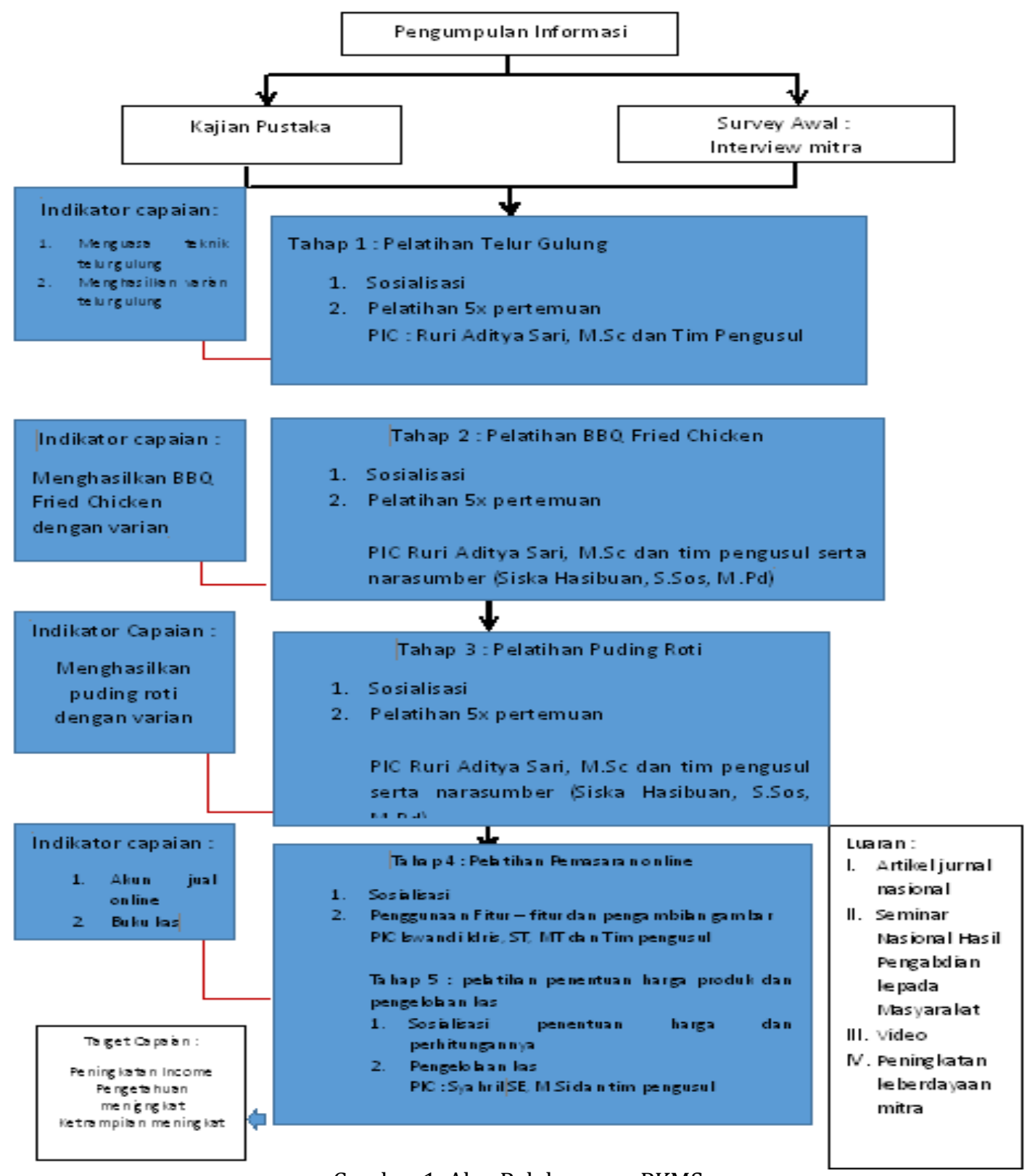

Gambar 1. Alur Pelaksanaan PKMS

\section{HASIL DAN PEMBAHASAN}

PKMS ini memberikan dampak yang sangat baik bagi mitra, hal ini dibuktikan dari hasil penilaian melalui kuisioner. Mitra merasa sangat puas dan senang terhadap adanya kegiatan selama menunggu anak pulang sekolah. Berdasarkan hasil wawancara dengan ketua kelompok, 
beliau menyatakan bahwa terjadi perubahan yang drastis pada suasana menunggu anak sekolah. Para orang tua semua memiliki kesibukan memasak dan berwirausaha. Selan itu, tidak nampak kesenjangan antara orangtua bekerja dan orang tua tidak bekerja, karena yang tidak bekerja sekarang disibukkan dengan kegiatan memasak dan berwirausaha. Makanan dan jajanan anak juga lebih bernilai gizi daripada sebelumnya. Mitra merasa sangat senang sekali adanya kegiatan PKMS ini, karena dapat menambah keahlian, menambah ilmu pengetahuan mereka dan mereka menjadi mendapatkan income tambahan. Gambar 2 merupakan grafik gambaran hasil kuisioner setelah pelaksanaan PKMS.

Berdasarkan gambar 3, diperoleh bahwa program ini menambah pengetahuan mitra sebanyak $80 \%$ dan mitra yang kreatif meningkat sebanyak 65\%. Selanjutnya, sebanyak 6\% mitra menghasilkan produk, terdapat sebanyak $5 \%$ mitra yang melanjutkan menjadi wirausaha secara online. Melalui pemasaran online tersebut, mitra menjelaskan bahwa pendapatan mereka bertambah. Sebanyak 5\% mitra yang menyatakan pendapatan bertambah. Mitra yang terampil mencapai 75\% dan mitra yang menyatakan kesejahteraan hidup meningkat sebanyak 5\%.

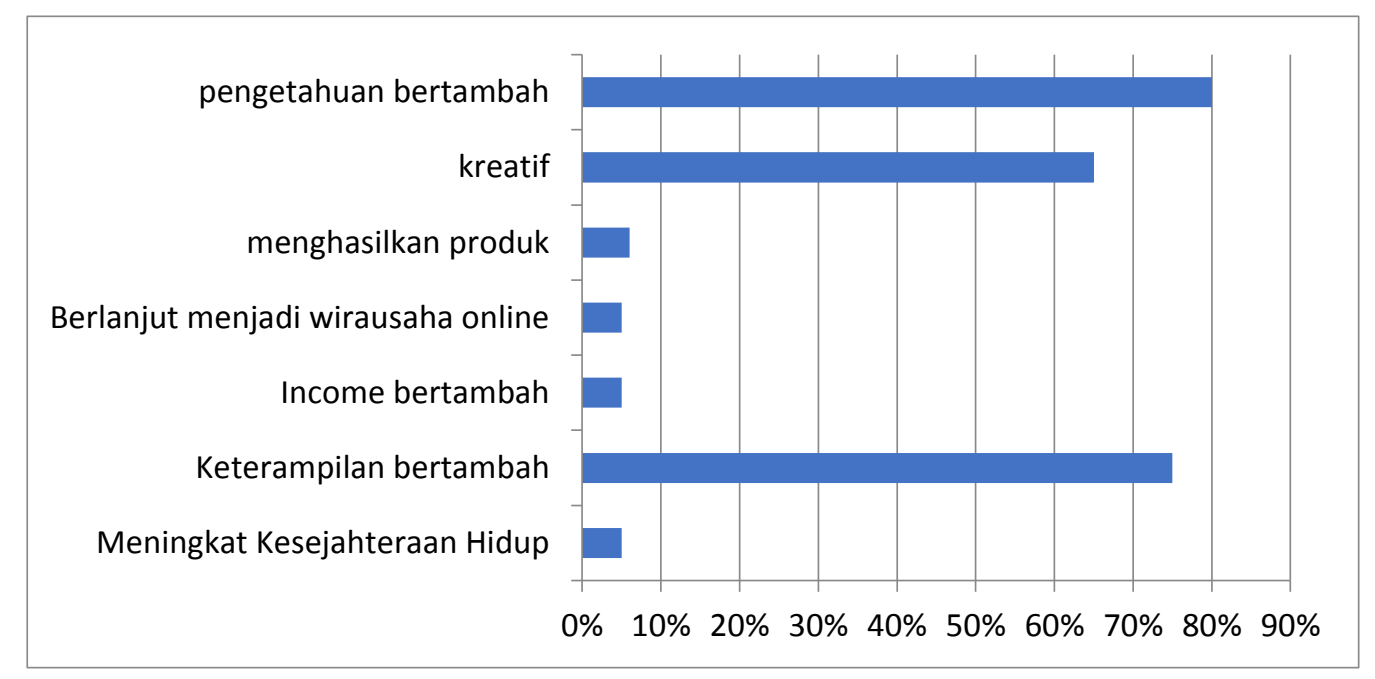

Gambar 2. Hasil PKMS terhadap Mitra

Hal ini sangat jauh berbeda dengan keadaan sebelum adanya kegiatan PKMS. Gambar 3 menunjukkan perbandingan keadaan sebelum adanya PKMS.

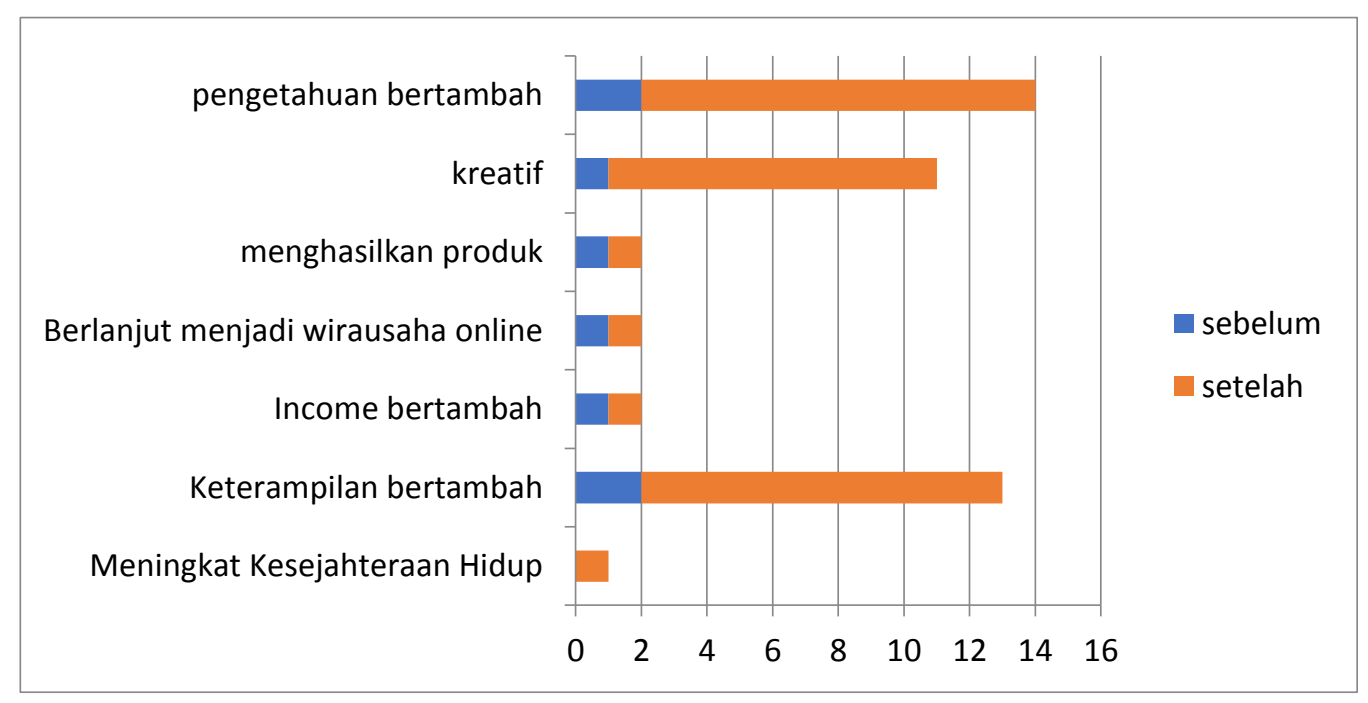

Gambar 3. Perbandingan Capaian Mitra hasil PKMS 


\section{Pelatihan Telur Gulung}

Pelatihan telur gulung yang diberikan sebanyak 3 jenis telur gulung yaitu telur gulung biasa, telur gulung sosis dan telur gulung abon. Namun setelah pelatihan, kelompok ibu orangtua siswa kelas 1 dan kelas 2 SD Ar Rasyid melakukan inovasi telur gulung (Gambar 4).
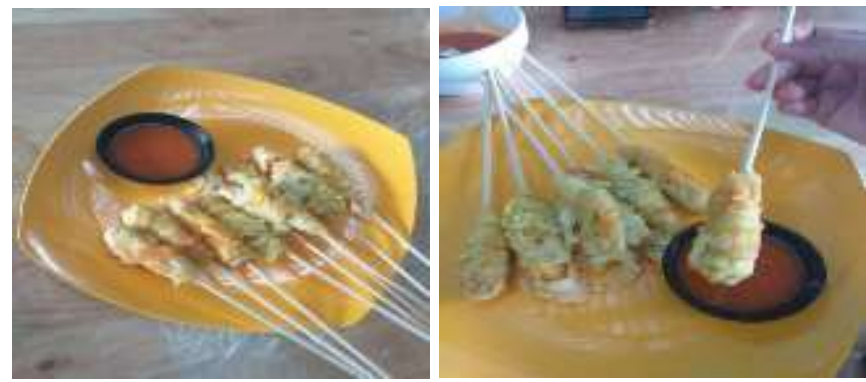

Gambar 4. Hasil Kreasi Peserta Telur gulung

\section{Pelatihan BBQ Fried Chicken}

Pelatihan $B B Q$ Fried Chicken yang diberikan sebanyak 1 jenis $B B Q$ Fried Chicken. Namun setelah pelatihan, kelompok ibu orangtua siswa kelas 1 dan kelas 2 SD Ar Rasyid melakukan inovasi $B B Q$ Fried Chicken dengan level kepedasan yang berbeda (Gambar 5).
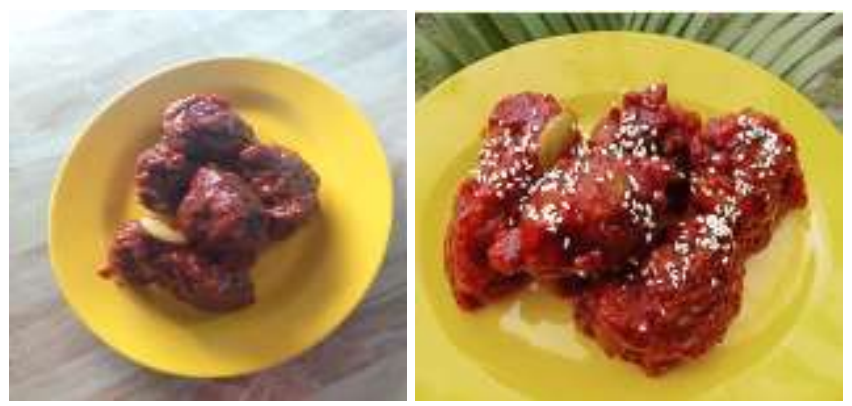

Gambar 5. Hasil Kreasi Peserta Telur gulung

\section{Pelatihan Puding Roti}

Pelatihan puding roti yang diberikan sebanyak 1 jenis puding roti. Namun setelah pelatihan, kelompok ibu orangtua siswa kelas 1 dan kelas 2 SD Ar Rasyid melakukan inovasi Puding Roti dengan rasa yang berbeda (Gambar 6).
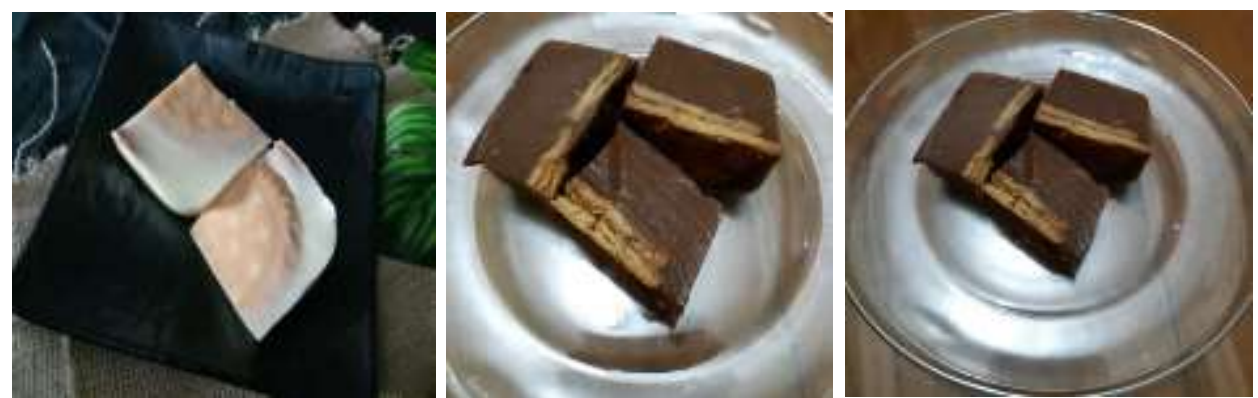

Gambar 6. Hasil Kreasi Peserta Puding Roti

\section{Pelatihan Pemasaran Online}

Hasil dari pelatihan pemasaran online ini dapat dilihat dari media sosial para peserta PKMS yang mulai mengisinya dengan promosi - promosi penjualan masakan yang telah diajarkan selama kegiatan PKMS. Selain memuat gambar - gambar produk yang telah diajarkan, 
peserta PKMS juga mulai pandai mempromosikan produk lainnya seperti pakaian, aksesoris dan lainnya.

\section{Pelatihan Penentuan Harga Pokok dan Pengelolaan Kas}

Pelatihan ini memberikan hasil kepada mitra berupa keahlian dalam menghitung biaya produksi dan menentukan harga jual produk, selain itu mitra menjadi lebih bijak dalam mengelola keuangan khususnya kas. Sebelumnya mitra tidak mempunyai perencanaan dalam pengelolaan keuangan sehingga mereka mengeluhkan bahwa mereka tidak mempunyai modal untuk usaha. Namun ternyata, setelah adanya pelatihan ini, pengelolaan keuangan mereka menjadi lebih baik, tidak ada lagi kesenjangan sosial diantara mitra dan peserta bersemangat dalam berusaha.

Harga telur gulung rata - rata dijual dengan harga Rp. 1000/tusuk nya, sedangkan harga puding roti dijual rata - rata Rp. 5000/box dan harga ayam bbq dijual seharga Rp. 20.000/porsi. Harga tersebut mampu membuat mitra mendapatkan keuantungan sekitar Rp. 200/ tusuk untuk telur gulung, Rp. 1500/box puding roti dan Rp. 5000/porsi ayam BBQ.

Menurut Prayuda et. al (2018) memasak adalah kegiatan yang biasa dilakukan dalam kehidupan, memasak merupakan hobi bagi sebagian orang. Selain itu, dengan memasak dapat menghasilkan tambahan pendapatan keluarga. Hal ini dapat meningkatkan kualitas hidup seseorang. Melalui solusi tersebut maka para ibu orangtua siswa akan memanfaatkan waktu menunggu anak mereka pulang sekolah dengan belajar memasak, selanjutnya menghasilkan produk yang dapat dijual. Kemudian, produk makanan tersebut dapat dikembangkan sesuai dengan kreativitas dan keinginan masing - masing. Ketika mitra sudah menguasai teknik memasak tersebut, maka selanjutnya mitra dapat menjadi seorang wirausaha sehingga mampu meningkatkan kesejahteraan keluarga. Melalui pelatihan memasak juga akan melatih kesabaran, kreativitas dan ketelitian para ibu, sehingga mereka akan terbiasa untuk lebih sabar dalam kehidupan sehari - hari. Solusi yang diberikan kepada mitra ini sejalan dengan komitmen dan rencana pemerintah terhadap ekonomi kreatif, Pemerintah menyatakan bahwa pada tahun 2018, sektor makanan dan minuman berhasil menyumbangkan produk domestik bruto (PDB) nasional sebesar 6,34\% dan termasuk lima besar penyumbang PDB terbesar industri lain seperti industri kimia, tekstil, alat angkut dan teknologi (Kementrian Perindustrian, 2019). Menurut Saraswati dan Suminar (2014) berkreasi dapat mengasah kemampuan dalam menyelesaikan masalah, penyesuaian diri dan peningkatan kualitas hidup. Selain itu, kreativitas dapat membantu memecahkan persoalan yang menghadang proses pembangunan (Saraswati \& Suminar, 2014). Produk industri kreatif selalu tampil dengan keunikan tersendiri dan memiliki ciri khas sehingga mampu menciptakan citra sebuah kota dan menarik wisatawan dengan kuliner khas daerah, sehingga melalui peran pariwisata yang dapat memberikan pengalaman dan pembelajaran bagi wisatawan (Diana, et.al, 2017).

\section{KESIMPULAN}

Dari PKMS yang dilakukan pada mitra Kesimpulannya ialah mitra merasa sangat puas dan senang atas pelatihan yang dijalankan, mitra berhasil meningkat ketrampilan dan pengetahuannya, mitra menjadi kelompok mitra produktif ekonomi karena mendapatkan tambahan income dan meningkatnya kesejahteraan hidup dari usaha menjual produk PKMS secara online. pengetahuan mitra sebanyak $80 \%$ dan mitra yang kreatif meningkat sebanyak $65 \%$. Selanjutnya, sebanyak 6\% mitra menghasilkan produk, terdapat sebanyak $5 \%$ mitra yang melanjutkan menjadi wirausaha secara online. Melalui pemasaran online tersebut, mitra menjelaskan bahwa pendapatan mereka bertambah. Sebanyak 5\% mitra yang menyatakan pendapatan bertambah.

\section{SARAN}

Berdasarkan kesimpulan diatas maka saran, yaitu: agar lebih baik lagi, maka mitra diperlukan diberikan pelatihan tentang pembungkusan produk. 


\section{UCAPAN TERIMA KASIH}

Penulis mengucapkan terima kasih kepada Kementrian Riset, Teknologi dan Pendidikan Tinggi atas pendanaan hibah PKMS dengan nomor kontrak Nomor: 13/LL1/AM/2020.

\section{DAFTAR PUSTAKA}

Amrina, R., Zainuddin, A., Santi, A., \& Wibowo, P., A. (2019). Pendampingan Pembentukan Badan Usaha Milik Desa (BUMDES) Desa Kendasalem Wedung Demak, Dinamisia-Jurnal Pengabdian Kepada Masyarakat, 3(2), 235-243.

BAPPENAS, “Warta KUMKM," Membangun Budaya Kewirausahaan, pp. 1-7, Desember 2013.

Diana, P., Suwena, I., K., \& Wijaya, N., M., S. (2017). Peran dan pengembangan Industri Kreatif dalam Mendukung Pariwisata di Desa Mas dan Desa Peliatan, Ubud, Jurnal Analisis Pariwisata, vol. 17, no. 2, pp. 84-92.

Kementrian Perindustrian, Gurihnya Industri Kuliner Bikin Ekonomi Nasional Menggeliat, Koran SINDO, Minggu 06 Januari 2019.

Kompas.com, "Jumlah Entrepreneur di Indonesia Jauh dibawah Negara Maju Ini kata Jokowi," Kompas.com, Jakarta, 2018.

Prakoswa, R., H. (2018). Para Perempuan, Ini Porsisi Wanita dalam Ekonomi Indonesia, CNBC Indonesia, Jakarta.

Prayuda, A., F., Wibisono, S., \& Hadikurniawati, W. (2018). Implementasi untuk Rekomendasi Masakan Tradisional Jawa dengan Metode Case Based Reasoning Menggunakan Algoritma Similaritas Czekanowski, Prosiding SENDI_U, p. 487- 492.

Saraswati, L., P., \& Suminar, D., R. (2014). Pengaruh Permainan Konstruktif berupa Kerajinan Tangan dari Barang Bekas Terhadap Peningkatan Kreativitas Anak Kelas V SDN Ngagelrejo III/398 Surabaya, Jurnal Psikologi Pendidikan dan Perkembangan, vol. 3, no. 2, pp. 103-109.

Siadari, E. T. (2015). Partisipasi Angkatan Kerja Wanita Sudah Menikah di Indonesia, Surabaya: UNiversitas Airlangga.

Sukidjo, "Peran pendidikan Kewirausahaan dalam Pemberdayaan Masyarakat Miskin di Indonesia," Jurnal Economia, vol. 8, no. 1, pp. 33-41, 2012.

Yudha, E., K. (2017). Peningkatan Ekonomi Masyarakat Melalui Usaha Kerajinan Tangan Anyaman Bambu di Desa Rimpak Kecamatan Sapuran Kabupaten Wonosobo, Fakultas Dakwah dan Komunikasi Universitas Islam Negeri Sunan Kalijaga Yogyakarta, Yogyakarta. 